О. М. Носик

Національний фармацевтичний університет, м. Харків, Україна

\title{
ВІДКРИТІ ІННОВАЦІЙНІ СИСТЕМИ: ГОЛОВНІ ХАРАКТЕРИСТИКИ І НАПРЯМИ ІНТЕРНАЦІОНАЛІЗАЦІЇ
}

Розкриття особливостей та тенденцій інноваційного розвитку в сучасний період грунтусться на визначенні його нових характеристик, обумовлених постіндустріальними трансформаціями.

Мета написання статті - дослідження головних елементів відкритих національних інноваційних систем та напрямів їх включення у міжнародне інноваційне співробітництво. У ході виконання окреслених завдань використано методи системного та структурнофункціонального аналізу 3 метою обгрунтувати головні складники відкритих інноваційних систем та чинники і напрями їх формування та функціонування.

Наголошено, що головні характеристики відкритих інноваційних систем - це інноваційне підприсмництво, інноваційні мережі, інноваційна співпраця i партнерство, інноваційні кластери та екосистеми. Рушійною силою сучасного інноваційного процесу с підприсмницька інноваційна діяльність, що охоплюс всі стадії та сфери системного інноваційного процесу, спирається на інновації - технологічні, управлінські, ринкові, соціальні і забезпечує інноваційний розвиток суспільства.

Виявлено, що інноваційна співпраця передбачас залучення ії учасників до інноваційного процесу із застосуванням таких форм, як трансфер технологій, інформаційний обмін, наукові та освітні програми, комерційний обмін інноваційними продуктами. Інноваційне партнерство поєднує інноваційні ресурси та діяльність їх учасників - створення інноваційних підприємств, сумісне здійснення інноваційних проектів. У сучасний період інноваційна співпраця i партнерство розвиваються на рівні корпорацій, галузей та секторів національної економіки й на міжнародному рівні.

Розвиток інноваційної співпраці та партнерства залежить від формування й стану інноваційних екосистем як середовища відкритих інновацій. Під впливом глобальних чинників розвитку інноваційних кластерів притаманна тенденція інтернаціоналізації інноваційної діяльності на основі міжнародної кооперації кластерів різних країн.

Інноваційний розвиток приводить до певних трансформацій людського капіталу, зростання рівня його інновативності й інноваційності. Інтернаціоналізація людського капіталу інновацій відбувається на основі розвитку міжнародної науково-технічної співпраці, здійснення соціогуманітарних програм.

Напрямами формування відкритих інноваційних систем с розвиток інноваційного підприсмництва, інноваційних мереж, інноваційного співробітництва i партнерства, інноваційних екосистем та кластерів. Ядро відкритих інноваційних систем складає людський капітал інноваційного розвитку.

Наукова новизна дослідження полягас у визначенні умов та чинників набуття інноваційними системами різного рівня відкритого характеру, обгрунтування їх складників та напрямів інтернаціоналізації. Практичне значення одержаних результатів - використання суб'сктами інноваційної діяльності матеріалів статті для організації інноваційного процесу на основі принципів відкритих інновацій.

Подальше дослідження зазначеної наукової проблеми спрямовуватиметься на обгрунтування особливостей відтворення людського капіталу відкритих інноваційних систем.

Ключові слова: відкриті інноваційні системи; інноваційні мережі; інноваційна співпраця і партнерство; міжнародні інноваційні кластери; людський капітал інновацій; інтернаціоналізація інноваційних систем.

(C) Носик О. М., 2016 


\section{Е. Н. Носик \\ Национальный фармачевтический университет, г. Харьков, Украина}

\section{ОТКРЫТЫЕ ИННОВАЦИОННЫЕ СИСТЕМЫ: ОСНОВНЫЕ ХАРАКТЕРИСТИКИ И НАПРАВЛЕНИЯ ИНТЕРНАЦИОНАЛИЗАЦИИ}

Раскрытие особенностей и тенденций инновационного развития в современный период базируется на определении его новых характеристик, обусловленных постиндустриальными трансформациями.

Цель написания статьи - исследование главных элементов открытых национальных инновационых систем и направлений их включения в международное инновационное сотрудничество. В ходе выполнения поставленных задач использовались методы системного и структурно-функционального анализа с целью обоснования главных составляющих открытых инновационных систем и факторов и направлений их формирования и функционирования.

Отмечено, что главными характеристиками открытых инновационных систем является инновационное предпринимательство, инновационые сети, инновационное сотрудничество и партнерство, инновационные кластеры и экосистемы. Движущей силой современного инновационного процесса является предпринимательская инновационная деятельность, охватывающая все стадии и сферы системного инновационного процесса, опирается на инновации - технологические, управленческие, рыночные, социальные, и обеспечивает инновационное развитие общества.

Выявлено, что инновационное сотрудничество предусматривает включение участников в инновационный процесс с применением таких форм, как трансфер технологий, информационный обмен, научные и образовательные программы, коммерческий обмен инновационными продуктами. Инновационное партнерство базируется на сочетании инновационных ресурсов и деятельности их участников - создание инновационных предприятий, совместное осуществление инновационных проектов. В современный период инновационное сотрудничество и партнерство развиваются на уровне корпораций, отраслей и секторов национальной экономики и на международном уровне.

Развитие инновационного сотрудничества и партнерства зависит от формирования и состояния инновационных экосистем как среды открытых инноваций. Под влиянием глобальных факторов развитию инновационных кластеров присуща тенденция интернационализации инновационной деятельности на основе международной кооперации кластеров разных стран.

Инновационное развитие приводит к определенной трансформации человеческого капитала, росту уровня его инновативности и инновационности. Интернационализация человеческого капитала инноваций осуществляется на основе развития международного научно-технического сотрудничества, реализации социогуманитарных программ.

Направлением формирования открытых инновационных систем является развитие инновационного предпринимательства, инновационных сетей, инновационного сотрудничества и партнерства, инновационных экосистем и кластеров. Ядро открытых инновационных систем составляет человеческий капитал инновационного развития.

Научная новизна статьи заключается в определении условий и факторов приобретения инновационными системами различного уровня открытого характера, обоснование их составляющих направлений интернационализации. Практическое значение полученных результатов - использование субъектами инновационной деятельности материалов статьи для организации инновационного процесса на основе принципов открытых инноваций.

Дальнейшее исследование указанной научной проблемы будет направлено на обоснование особенностей воспроизводства человеческого капитала открытых инновационных систем.

Ключевые слова: открытые инновационные системы, инновационные сети, инновационное сотрудничество и партнерство, международные инновационные кластеры, человеческий капитал инноваций, интернационализация инновационных систем. 


\section{O. M. Nosyk \\ National university of pharmacy, Kharkiv, Ukraine \\ OPEN INNOVATION SYSTEMS: MAIN CHARACTERISTICS AND TRENDS OF INTERNATIONALIZATION}

Exploring the peculiarities and trends in innovation development in modern conditions is based on defining its new characteristics caused by postindustrial transformations.

The aim of writing this article is to study the main elements of open national innovation systems and trends of their integration into international innovation cooperation. In the course of performing the set tasks, we used methods of system and structural-functional analysis to substantiate the main components of open innovation systems and the trends in their formation and operation.

It was stressed that the main characteristics of open innovation systems are innovation entrepreneurship, innovation networks, innovation cooperation and partnership, innovation clusters and ecosystems. The driving force of modern innovation process is the entrepreneurial innovation activity, covering all stages and areas of system innovation process, relying on innovations in technology, management, market, social and providing for innovative development of the society.

It was discovered that the innovative collaboration involves its participants in the innovation process with the use of such forms as technology transfer, information exchange, research and educational programs, commercial exchange of innovative products. Innovation partnership combines innovation resources and activities of the participants - setting up innovative enterprises, joint implementation of innovative projects. In the modern period, innovation collaboration and partnership develop at the level of corporations, industries and sectors of national economy and on the international level.

Development of innovative cooperation and partnership depends on the formation and status of innovation ecosystems as the medium of open innovations. Influenced by global factors, the development of innovation clusters is characterized by the trend of internationalization of innovation activities on the basis of international cooperation among clusters of different countries.

Innovation development leads to certain transformations in the human capital, growth in the level of its innovativeness and innovation. Internationalization of human capital in innovation occurs on the basis of the development of international scientific and technical cooperation and implementation of social humanitarian programs.

Directions of formation of open innovation systems are the development of innovation entrepreneurship, innovation networks, innovation cooperation and partnership, innovation ecosystems and clusters. The core of open innovation systems is the human capital of innovation development.

The scientific novelty of this research made it possible to determine the conditions and factors for the innovation systems to reach various levels of open nature and substantiation of their components and areas of internationalization. The practical significance of the obtained results is application of the materials of this paper by the subjects of innovation activity for managing the innovation process based on the principles of open innovations.

Further research into defined scientific problem will be focused on the substantiation of features of renewal of human capital of open innovation systems.

Keywords: open innovation systems, innovation networks, innovation collaboration and partnership, international innovation clusters, human capital of innovation, internationalization of innovation systems.

Вступ. Розкриття особливостей i тенденцій інноваційного розвитку в сучасний період має грунтуватися на його нових характеристиках, обумовлених постіндустріальними трансформаціями, серед яких найактуальнішою $є$ формування відкритих інноваційних систем різного рівня - регіональних, національних, міжнародних. Теоретичну основу їх аналізу становить концепція відкритих інновацій, яку вперше обгрунтував Генрі Чесбро - професор, виконавчий директор Центру відкритих інновацій школи бізнесу імені У. Хааса Каліфорнійського університету. Окремі аспекти й напрями формування й функціонування відкритих інноваційних систем розкрито у працях таких учених, як П. А. Авдєєв, У. Дж. Баумоль, В. С. Дубовик, Д. В. Жерновий, М. О. Канаєва, М. С. Ки’рякова, 

М. В. Колесник,
А. С. Никифоров,
I. А. Павленко,
С. Г. Панченко,

Н. В. Смородинська, Л. І. Федулова, Г. А. Яшева.

Слід підкреслити, що відкриті інновації є дієвий чинник підвищення інноваційної активності суб'єктів господарювання. Це особливо актуально для України, оскільки в сучасний період інноваційна активність національних підприємств невелика та продовжує зменшуватися.

Постановка завдання. Метою написання статті $є$ характеристика головних елементів відкритих національних інноваційних систем та напрямів їх включення у міжнародну інноваційну співпрацю. У ході виконання поставлених завдань використовувалися методи системного та структурно-функціонального аналізу 3 метою обгрунтувати головні складники відкритих інноваційних систем та чинників i напрямів їx формування та функціонування. Теоретичну основу дослідження становлять концепція відкритих інновацій Г. Чесбро, теорії економіки знань та інноваційної економіки, праці вітчизняних і закордонних учених.

Результати. Закриті інноваційні процеси не забезпечують необхідного рівня комерціалізації і прибутковості інноваційних розробок, оскільки фірма має ресурсні обмеження щодо здійснення за власний рахунок усіх стадій інноваційного процесу, що призводить до неможливості впровадження новацій та недоведення до стадії масового збуту інноваційної продукції. Цілком імовірна може бути ситуація, коли внаслідок незабезпечення новації необхідного рівня доходу, фірма не має коштів для нового інноваційного циклу. Крім того, через часові розриви між стадіями інноваційного процесу знецінюються нові розробки, а інтелектуальні продукти втрачають новизну, отже, фірма не компенсує витрати, пов'язані із самостійним здійсненням повного циклу інноваційної діяльності, та не отримує інноваційної ренти.

Як визначають Є. Г. Панченко, М. Є. Кир'якова, нині парадигма закритих інновацій, вихідним пунктом якої є впевненість у можливостях компанії генерувати ідеї, створювати на їх основі продукт, виходити з ним на ринок та поширювати його, обслуговувати, фінансувати лише за рахунок власних ресурсів, змінилася парадигмою відкритих інновацій [1]. Відкриті інновації - це основа формування та функціонування інноваційних систем відкритого характеру, які створюють, за визначенням Г. Чесбро, можливості входу, виходу та переходу інновацій на всіх стадіях інноваційного процесу [2, с. 3]. На думку П. Авдєєва, відкриті національні інноваційні системи грунтуються на взаємодії інститутів у їх широкому навколишньому середовищі через соціальну й мережну взаємодію, технологічні траєкторії, науково-технічну політику, структуру ринків, національну політику, інтелектуальну власність, міжнародні інвестиційні та торговельні угоди. Їх ядро становлять підприємці, які є одночасно і виробники, і споживачі інноваційної продукції на різних етапах інноваційного процесу та мають зворотний зв'язок із кінцевими споживачами інноваційної продукції [3]. Головні характеристики відкритих інноваційних систем - це інноваційне підприємництво, інноваційні мережі, інноваційна співпраця і партнерство, інноваційні кластери та екосистеми.

Відомий американський економіст Вільям Дж. Баумоль виокремлює такі типи підприємців, як репликативні підприємці (створюють підприємства подібні існуючим) та інноваційні підприємці (винаходять нові підприємства) [4]. Рушійною силою сучасного інноваційного процесу є саме інноваційні підприємці.

У сучасній науковій економічній думці існують такі визначення інноваційного підприємництва:

- у вузькому розумінні, це діяльність підприємців з упровадження інновацій. А. Є. Никифиров наголошує: «Якщо інноваційна праця пов'язана насамперед із 
створенням інновацій, то інноваційне підприємництво -3 ï комерціалізацією» [5, с. 42];

- у широкому розумінні, це підприємницька діяльність на всіх стадіях і в усіх сферах інноваційного процесу.

Українська дослідниця I. А. Павленко, розкриваючи зміст інноваційного підприємництва, поєднує наявні підходи до його визначення та вважає: на мікроекономічному рівні - це діяльність певного суб'єкта підприємництва 3 використання результатів наукових досліджень і розробок або інших науковотехнічних досягнень, що обумовлює виникнення якісно нових і кращих за своїми властивостями товарів та послуг, реалізованих на ринку, або технологій, використаних у практичній діяльності; на макроекономічному рівні - це модель розширеного економічного відтворення на основі впровадження інновацій у всі сфери суспільного життя; у політекономічному сенсі - це підсистема економічних відносин, сформованих для створення, упровадження й розширеного відтворення нововведень [6, с. 14-15 ].

На нашу думку, концепції відкритих інновацій відповідає широке розуміння інноваційного підприємництва як ядра відкритих інноваційних систем, це підприємницька інноваційна діяльність, що охоплює всі стадії та сфери інтегративного системного інноваційного процесу, спирається на інновації технологічні, управлінські, ринкові, соціальні та забезпечує інноваційний розвиток суспільства.

Інноваційні мережі та розвиток інноваційного підприємництва становлять основу співпраці та партнерства учасників сучасного інноваційного процесу на рівні підприємств, регіонів, на національному i міжнародному рівнях. На обгрунтовану думку Л. Федулової, у концепції відкритих інновацій знайшла своє втілення проблема створення технологій на основі наукової співпраці, розвитку інновацій на принципах відкритості в проведенні спільних науково-дослідних й дослідно-конструкторських робіт (НДДКР) [7, с. 29].

Зміст понять інноваційної співпраці й інноваційного партнерства взаємопов'язані, але не тотожні. Інноваційна співпраця передбачає включення іii учасників у інноваційний процес певного рівня із застосуванням таких форм, як трансфер технологій, інформаційний обмін, наукові та освітні програми, комерційний обмін інноваційними продуктами тощо. Інноваційне партнерство грунтується не тільки на науково-технічній співпраці, а й на поєднанні інноваційних ресурсів та діяльності їх учасників, тобто на створенні інноваційних підприємств, сумісному здійсненні інноваційних проектів.

У сучасний період інноваційна співпраця і партнерство розвиваються не тільки на рівні корпорацій, галузей та секторів національної економіки, а й на міжнародному рівні. Одним із семи пріоритетних напрямів стратегії Свропейського Союзу «Європа-2020. Стратегія розумного, стійкого і всеосяжного зростання» визначено формування інноваційного союзу на базі таких заходів:

- завершення створення Європейського дослідного простору (European Research Area);

- поліпшення умов для бізнесу та інновацій: створення єдиного патенту ЄС

(EU Patent) i спеціалізованого Патентного суду (Patent Court), модернізація загальних положень про авторське право і товарні знаки, поліпшення доступу малих і середніх підприємств до інструментів охорони інтелектуальної власності;

- упровадження «Свропейських інноваційних партнерств» (European Innovation Partnerships) між СС і країнами-членами для прискорення розвитку й перерозподілу технологій; 
- зміцнення і розвиток політичних інструментів ЄС для підтримки інновацій (структурних фондів, фондів розвитку сільських районів, рамкових програм), у тому числі завдяки тісній співпраці з Європейським інвестиційним банком, спрощенню адміністративних процедур для отримання доступу до фінансування, особливо МСП;

- розширення партнерських відносин та зміцнення зв'язків між освітою, бізнесом і наукою, сприяння розвитку підприємництва шляхом надання підтримки молодим інноваційним компаніям [8].

Отже, європейська стратегія інноваційного економічного розвитку спрямована на створення умов для інноваційної співпраці і партнерства, які, на переконливу думку Д. В. Жернового, можуть забезпечити додатковий позитивний ефект від «перетоку знань», що сприятиме нарощуванню інноваційного потенціалу українськими компаніями [9].

Розвиток інноваційної співпраці й партнерства залежить від формування і стану інноваційних екосистем як середовища відкритих інновацій. «Інноваційна екосистема - це сукупність організаційних, структурних i функціональних компонентів (інституцій) та їх взаємовідносин, задіяних у процесі створення та застосування наукових знань та технологій, що визначають правові, економічні, організаційні та соціальні умови інноваційного процесу та забезпечують розвиток інноваційної діяльності як на рівні підприємства, так і на рівні регіону та країни в цілому за принципами самоорганізації» [10, с. 26]. Як підкреслює Н. Смородинська, префікс «еко» у понятті «система» вказує на те, що в сучасних умовах інновації зароджуються колективно, у певному мережному середовищі, заснованому на горизонтальних зв'язках юридично незалежних учасників [11].

Прикладом регіонального інноваційного середовища може бути перша в Україні інноваційна екосистема «Sikorsky Challenge», створена Національним технічним університетом України «КПІ» та науковим парком «Київська політехніка». Ї̈̈ складниками є: стартап-школа, діяльність якої спрямована на формування знаннєвого потенціалу майбутніх інноваційних підприємців, інноваційний фестиваль як конкурс інноваційних стартап-проектів 3 метою їх оцінити та презентувати інвесторам, інноваційний бізнес-інкубатор із запуску стартап-компаній, інноваційно-технологічне середовище «Sikorsky Lab», Центр інтелектуальної власності, Венчурний фонд Sikorsky Challenge та інші фонди [12; 13].

Слід підкреслити, що інноваційний $\mathrm{i}$ людський розвиток тісно взаємопов'язані. 3 одного боку, по-перше, основу сучасного інноваційного розвитку становлять креативні здібності людини: створювати, освоювати, накопичувати та використовувати нові знання у різних сферах діяльності. Людський капітал як вартість запасу накопичених людиною знань, здібностей, умінь та навичок, що збільшується у процесі іiі використання в різних сферах суспільної життєдіяльності, $є$ ресурс інноваційного розвитку, тобто ресурс створення, упровадження, використання та поширення інтелектуальних продуктівновацій як чинника різноманітних змін у суспільстві в цілому так і у його різних сферах - виробничій, соціальній, культурній тощо та на різних рівнях: підприємство, галузь, регіон, країна, світова економіка. По-друге, розвиток людини як носія інноваційного людського капіталу $\epsilon$ метою соціально-економічного розвитку оскільки саме людина є творцем, виробником і кінцевим споживачем інноваційних продуктів та послуг.

3 іншого боку, інноваційний розвиток призводить до певних трансформацій (змістовних, структурних, функціональних) людського капіталу, узагальнюючим 
проявом яких є зростання рівня його інновативності як здатності до сприйняття інновацій і інноваційності - спрямованості на створення, впровадження та використання інновацій. Відкриті інновації характеризуються змінами та зростанням ролі людського капіталу у інноваційному розвитку, його трансформацією від людського капіталу створення та впровадження інновацій у межах лінійного інноваційного процесу до людського капіталу науково-технічної, виробничої, маркетингової діяльності, внутрішніх і зовнішніх інноваційних мереж, інноваційної співробітництва і партнерства національного і міжнародного рівнів, національних інноваційних систем.

У Європейському Союзі інтернаціоналізація людського капіталу інновацій здійснюється на основі розвитку міжнародного науково-технічного співробітництва шляхом реалізації Рамкових програм, які здійснюються з 1984 року і по теперішній час. Спеціальні програми, спрямовані на розвиток людських ресурсів, які $\epsilon$ складовими шостої, сьомої Рамкових програм і програми «Горизонт-2020». У сучасний період змінюються підходи ЄС до визначення ролі людських ресурсів у інноваційному та науково-технічному розвитку у напряму визнання їх пріоритетного значення. Якщо у програмах РП6 і РП7 розглядалися залучення та розвиток людських ресурсів як окремі спеціальні програми, то у програмі «Горизонт-2020» це визначено одним із найважливіших її компонентів.

Одним із пріоритетних напрямів Європейської інноваційної науковотехнічної програми «EUREKA» (European Research Coordination Agency), заснованої в 1985 р. (Україна із 1993 р. стала асоційованим членом програми, а 3 червня 2006 р. набула статусу повноправного члена програми EUREKA) i спрямованої на розвиток міжнародної співпраці в сфері прикладних досліджень, $\epsilon$ такі, як медичні технології, біотехнології, екологія [14]. Пріоритетами програми «Європа-2020», спрямованої на створення Свропейського інноваційного союзу, визнано сприяння високому рівню зайнятості населення та боротьба з бідністю

Таким чином, програми ЄС із міжнародної науково-технічної та інноваційної співпраці мають значний соціальний складник і сприяють інтернаціоналізації національного людського капіталу країн, що беруть у них участь, розширенню чинників та простору його інноваційного відтворення, транснаціональній мобільності його власників.

На якісний розвиток та інтернаціоналізацію відтворення людського капіталу спрямовано соціогуманітарні програми ЄС: освітні, культурні, з охорони здоров'я тощо, серед яких:

- освітні програми;

- культурні програми, такі, як «Креативна Європа», спрямована на міжнародну культурну співпрацю, забезпечення доступу до культурних здобутків різних країн, фінансування підготовки та реалізації проектів у сфері культури та медіа;

- програми співпраці з охорони здоров’я, наприклад, Європейська мережа 3 технологій охорони здоров'я (European network for Health Technology Assessment), заснована у 2005 р. з метою оптимізувати використання ресурсів охорони здоров’я та забезпечити співпрацю країн Європи у цій сфері [15];

- програми сприяння зайнятості, серед яких програма «Молодь у русі» як частина програми «Свропа-2020», спрямована на забезпечення виходу молодих спеціалістів на європейський ринок праці.

У цілому європейські програми інноваційної, науково-технічної, соціокультурної співпраці та розвиту безпосередньо створюють умови для 
інтернаціоналізації та інноваційного відтворення людського капіталу в європейському просторі.

Сучасною організаційною формою інноваційної діяльності в територіальному аспекті $є$ регіональні й національні інноваційні кластери, у яких сконцентровано ресурси інновацій, у тому числі й людський капітал інноваційного розвитку. Кластерний підхід широко застосовано для ефективної організації та керування виробничими, науковими, соціальними комплексами на основі співпраці та мереж підприємств, організацій, установ у певних галузях національної економіки. У Європейському кластерному меморандумі, підготовленому за ініціативи Європейської комісії Центром стратегії та конкурентоспроможності, Стокгольмською школою економіки, визначено, що кластери - це регіональні центри концентрації спеціалізованих компаній і організацій, пов'язаних один 3 одним численними каналами, які створюють сприятливе середовище для інновацій. Вони роблять можливими «відкриті інновації», тобто створення і вдосконалення нових ідей у мережі, що складається 3 компаній і організацій, які співпрацюють один 3 одним. Ці групи компаній та організацій сприяють усуненню бар'єрів для перетворення нових ідей у нові продукти та отримання максимальної вигоди від глобалізації. В умовах сучасної конкуренції всі кластери повинні бути орієнтовані на інноваційний розвиток.

Інноваційний кластер - це форма організації інноваційної діяльності шляхом територіальної концентрації та використання ресурсів (матеріальних, інтелектуальних, організаційних, людських тощо) інновацій на всіх стадіях інноваційного процесу. За визначенням В. Шовкалюка, інноваційний кластер - це цілісна система підприємств і організацій з виробництва готового інноваційного продукту, що вміщує у себе весь інноваційний ланцюжок від розвитку фундаментальної наукової ідеї до вироблення та дистрибуції готової продукції [16]. Це мережа підприємств і організацій, створена на засадах довгострокових контрактів, форма мережної взаємодії між фірмами [17].

Одним із пріоритетних ресурсів ефективного функціонування інноваційного кластера є людський капітал. Як влучно визначає Д. Смолич, саме людина, іiі інтелект, креативне бачення генерують інноваційний ефект i визнаються соціальною цінністю у процесі формування кластера [18].

Розвитку інноваційних кластерів притаманна тенденція інтернаціоналізації інноваційної діяльності на основі міжнародної кооперації кластерів різних країн під впливом глобальних чинників. Як закріплено в Свропейському кластерному меморандумі, Європі потрібна більш сильна транснаціональна кооперація між кластерами та кластерними ініціативами, яка б дала змогу їм переймати один в одного успішний досвід. Слід посилювати транснаціональну кооперацію між кластерними ініціативами і таким чином сприяти виникненню стратегічних бізнесзв'язків і сервісних платформ, які допомагають використовувати додаткові сильні сторони й компетенцію різних кластерів [19]. У Програмі діяльності КМУ «Український прорив: для людей, а не для політиків», що затверджена Постановою КМУ України від 16.01.2008 р. № 14, вказано на необхідність участі вітчизняних суб'єктів господарювання в міжнародній науково-виробничій кооперації, зокрема у транснаціональних інноваційно-інвестиційних кластерах.

Інтернаціоналізація інноваційних кластерів $\epsilon$ чинник формування їх міжнародних форм. За визначенням Г. Яшевої, міжнародні кластери являють собою: 1) мережні об'єднання постачальників, виробників і покупців - резидентів різних держав, географічно зосереджені у транскордонному регіоні (транскордонний кластер); 2) міжнародні мережі національних кластерів 
(транснаціональний кластер), які співпрацюють i конкурують, пов'язані в технологічні ланцюжки i взаємодоповнюють один одного, співпрацюють 3 трансграничними установами (у т. ч. науковими, освітніми, інфраструктурами бізнесу), органами державного i міждержавного керування, a також 3 міжнародними організаціями 3 метою підвищити конкурентоспроможність суб'єктів кластера й національної економіки [20].

Кластеризація людського капіталу інноваційного розвитку, на нашу думку, має охоплювати два взаємопов'язані напрями: 1) накопичення людського капіталу інноваційних кластерів; 2) формування та розвиток кластерів людського капіталу інновацій як сконцентрованих за географічною ознакою суб'єктів і ресурсів його інноваційного відтворення та мережних відносин між ними. Ядром такого кластера може бути вищий навчальний заклад регіонального та національного рівнів, зовнішню мережу якого становлять відносини 3 інвесторами, власниками i користувачами людського капіталу.

У результаті інтернаціоналізації інноваційних кластерів, формування транскордонних i транснаціональних кластерів, їх людський капітал також інтернаціоналізується, а його відтворення здійснюється під впливом регіональних, національних та міжнародних чинників.

Висновки. Отже, спираючись на положення концепції відкритих інновацій, можна визначити такі характеристики відкритих інноваційних систем, як інноваційне підприємництво в усіх сферах суспільної життєдіяльності, спрямоване на нелінійний інтегрований інноваційний процес шляхом розвитку інноваційних мереж, інноваційної співпраці й партнерства, інноваційних екосистем та кластерів. Ядро відкритих інноваційних систем становить людський капітал інноваційного розвитку. Інтернаціоналізація інноваційного процесу - це основа формування людського капіталу міжнародних інноваційних мереж та кластерів.

Наукова новизна дослідження полягає у визначенні умов та чинників набуття інноваційними системами різного рівня відкритого характеру, обгрунтування їх складників та напрямів інтернаціоналізації.

Практичне значення одержаних результатів - використання суб'єктами інноваційної діяльності матеріалів статті для організації інноваційного процесу на основі принципів відкритих інновацій.

Подальше дослідження зазначеної наукової проблеми спрямовуватиметься на обгрунтування особливостей відтворення людського капіталу відкритих інноваційних систем.

\section{Бібліографічні посилання}

1. Панченко, Є. Г. Концепція відкритих інновацій та іiі використання транснаціональними корпораціями в Україні [Електронний ресурс] / Є. Г. Панченко, М. С. Кир'якова - Режим доступу: https://docviewer.yandex.ua/?url=http\%3A\%2F\%2Fjrnl.nau.edu.ua\%2Findex.php\%2FSR $\% 2$ Farticle $\% 2$ Fdownload $\% 2 F 6845 \% 2 F 7659 \&$ name=7659\&lang=uk\&c=567543869855.

- Заголовок з екрана.

2. Чесбро, Г. Открытые инновации. Создание прибыльных технологий [Текст] / Г. Чесбро; пер. с англ. В. Н. Егорова. - М.: Поколение, 2007. - 336 с.

3. Авдеев, П. А. Взаимодействие уровней формирования национальных инновационых систем в процессе интеграции в мировое экономическое пространство [Электронный ресурс] / П. А. Авдеев. - Режим доступа: http://www.ncfu.ru/uploads/doc/disser_avddev.pdf. - Загл. с экрана. 
4. Баумоль, У. Дж. Микротеория инновационного предпринимательства [Текст] / У. Дж. Баумоль; пер. с англ. Ю. Каптуревский. - М.: Ин-т Гайдара, 2013. $-432 \mathrm{c}$.

5. Никифоров, А. Є. Інноваційна діяльність: теорія і практика державного управління: монографія [Текст] / А. С. Никифоров. - К.: КНЕУ, 2010. - 420 с.

6. Павленко, I. А. Інноваційне підприємництво у трансформаційній економіці України: монографія [Текст] / І. А. Павленко. - К. : КНЕУ, 2007. - 248 с.

7. Федулова, Л. І. Технологічна політика: глобальний контекст та українська практика : монографія [Текст] / Л. І. Федулова. - К.: Київ. нац. торг.-екон. ун-т, 2015. $-844 \mathrm{c}$.

8. Підоричева, I. Інноваційна економіка - це економіка нестандартних рішень [Електронний ресур] / I. Підоричева. - Режим доступу: http://gazeta.dt.ua/macrolevel/innovaciyna-ekonomika-ce-ekonomika-nestandartnihrishen-_.html. - Заголовок з екрана.

9. Жерновий, Д. В. Структурний аналіз інноваційної діяльності підприємств України [Електронний ресурс] / Д. В. Жерновий. - Режим доступу: http://dspace.nbuv.gov.ua/bitstream/handle/123456789/86041/08-

Zhernovy.pdf?sequence $=1$. - Заголовок з екрана.

10. Федулова, Л. І. Інноваційні екосистеми: сутність та методологічні засади формування [Текст] / Л. І. Федулова, О. С. Марченко // Екон. теорія та право. 2015. - № 2(21). - С. 21-33.

11. Смородинская, Н. В. Сетевые инновационные экосистемы и их роль в динамизации экономического роста [Электронный ресурс] / Н. В. Смородинская. Режим доступа: http://inecon.org/docs/Smorodinskaya-Innovations-2014-07.pdf. - Загл. с экрана.

12. Sikorsky Challenge [Electronic resource]. - Режим доступу: http://www.sikorskychallenge.com $/ \% \mathrm{D} 0 \% \mathrm{~B} 3 \% \mathrm{D} 0 \% \mathrm{BB} \% \mathrm{D} 0 \% \mathrm{~B} 0 \% \mathrm{D} 0 \% \mathrm{~B} 2 \% \mathrm{D} 0 \% \mathrm{BD} \%$ D0\%B0\%D1\%8F/ua/. - Title from the screen.

13. Перша в Україні інноваційна екосистема [Електронний ресурс]. - Режим доступу: http://kpi.ua/ecosys. - Заголовок з екрана.

14. Програма «EUREKA» [Електронний ресурс]. - Режим доступу: http://cstei.lviv.ua/ua/item/718. - Заголовок з екрана.

15. Залізько, О. Базова модель НТА в Україні: застосування європейських підходів [Електронний ресурс] / О. Залізько, О. Піняжко. - Режим доступу: http://www.niss.gov.ua/articles/252/. - Заголовок з екрана.

16. Шовкалюк, В. С. Організаційні форми управління інноваційними кластерами [Електронний ресурс] / В. С. Шовкалюк. - Режим доступу: http://eep.org.ua/files/2009_.pdf. - Заголовок з екрана.

17. Дубовик, В. С. Формування інноваційних кластерів як методу активізації інноваційної діяльності в економіці регіону [Електронний ресурс] / В. С. Дубовик. Режим доступу: http://dspace.nbuv.gov.ua/bitstream/handle/123456789/5907/17Dubovyk.pdf?sequence=1. - Заголовок з екрана.

18. Смолич, Д. В. Концептуальні засади формування інноваційних кластерів в умовах транскордонного співробітництва регіонів [Електронний ресурс] / Д. В. Смолич. - Режим доступу: http://ena.lp.edu.ua:8080/bitstream/ntb /15940/1/31_206-211_Vis_725_Ekonomika.pdf. - Заголовок з екрана.

19. Европейский кластерный меморандум: Поддержка инноваций в Европе с помощью кластеров: План для политической реализации [Электронный ресурс]. Режим доступа: https://docviewer.yandex.ua/?url=http\%3A\%2F\%2Fbiznes.od.ua\% 


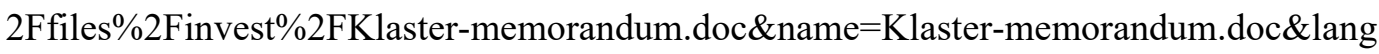

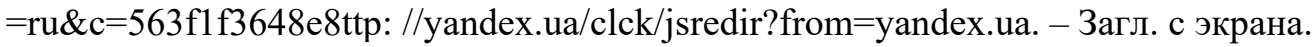

20. Яшева, Г. А. Формирование международных кластеров как фактор повышения конкурентоспособносты экономик России, Беларуси, Украины [Электронный pecypc] / Г. А. Яшева. - Режим доступа: http://p.120bal.ru/ekonomika/8211/index.html. - Загл. с экрана.

\section{Bibliographic references}

1. Panchenko, Ye. H. Kontseptsiia vidkrytykh innovatsii ta yii vykorystannia transnatsionalnymy korporatsiiamy v Ukraini [Electronic resource] / Ye. H. Panchenko, M. Ye. Kyriakova. - Access mode: https://docviewer.yandex.ua/?url=http\%3A\%2F\%2Fjrnl.nau.edu.ua\%2Findex.php $\% 2 F S R \% 2$ Farticle $\% 2 F d o w$ nload\%2F6845\%2F7659\&name $=7659$ \&lang $=$ uk\&c $=567543869855$.

2. Chesbro, G. Otkryityie innovatsii. Sozdanie pribyilnyih tehnologiy / G. Chesbro; per. s angl. V. N. Egorova. - M.: Pokolenie, 2007. - 336 s.

3. Avdeev P. A. Vzaimodeystvie urovney formirovaniya natsionalnyih innovatsionyih sistem $\mathrm{v}$ protsesse integratsii v mirovoe ekonomicheskoe prostranstvo [Electronic resource] / P. A. Avdeev. - Rezhim dostupu: http://www.ncfu.ru/uploads/doc/disser_avddev.pdf.

4. Baumol, U. Dzh. Mikroteoriya innovatsionnogo predprinimatelstva / U. Dzh. Baumol; per. s angl. Yu. Kapturevskiy. - M.: In-t Gaydara, 2013. - 432 s.

5. Nykyforov, A. Ye. Innovatsiina diialnist: teoriia i praktyka derzhavnoho upravlinnia: monohrafiia / A. Ye. Nykyforov. - KNEU, 2010. $-420 \mathrm{~s}$.

6. Pavlenko, I. A. Innovatsiine pidpryiemnytstvo u transformatsiinii ekonomitsi Ukrainy: monohrafiia / I. A.Pavlenko. - K. : KNEU, 2007. - 248 s.

7. Fedulova, L. I. Tekhnolohichna polityka: hlobalnyi kontekst ta ukrainska praktyka : monohrafiia / L. I. Fedulova. - K.: Kyiv. Nats. Torh. - ekon. un-t, 2015. - 844 s.

8. Pidorycheva, I. Innovatsiina ekonomika - tse ekonomika nestandartnykh rishen [Electronic resource] / I. Pidorycheva. - Access mode: http://gazeta.dt.ua/macrolevel/innovaciyna-ekonomika-ceekonomika-nestandartnih-rishen-_.html

9. Zhernovyi, D. V. Strukturnyi analiz innovatsiinoi diialnosti pidpryiemstv Ukrainy [Electronic resource] / D. V. Zhernovyi. - Access mode: http://dspace.nbuv.gov.ua/bitstream/handle/ 123456789/86041/08-Zhernovy.pdf?sequence=1

10. Fedulova, L. I. Innovatsiini ekosystemy: sutnist ta metodolohichni zasady formuvannia / L. I. Fedulova, O. S. Marchenko // Ekonomichna teoriia ta pravo. - 2015. - № 2(21). - S. 21-33.

11. Smorodinskaya, N. V. Setevyie innovatsionnyie ekosistemyi i ih rol $\mathrm{v}$ dinamizatsii ekonomicheskogo rosta [Electronic resource] / N. V. Smorodinskaya. - Rezhim dostupu: http://inecon.org/docs/Smorodinskaya-Innovations-2014-07.pdf.

12. Sikorsky Challenge [Electronic resource]. - Access mode: http://www.sikorskychallenge.com/\%D0\%B3\%D0\%BB\%D0\%B0\%D0\%B2\%D0\%BD $\% \mathrm{D} 0 \% \mathrm{~B} 0 \% \mathrm{D} 1 \% 8 \mathrm{~F} / \mathrm{ua} /$.

13. Persha $\mathrm{v}$ Ukraini innovatsiina ekosystema [Electronic resource]. - Access mode: http://kpi.ua/ecosys.

14. Prohrama «EUREKA» [Electronic resource]. - Access mode: http://cstei.lviv.ua/ua/item/718.

15. Zalizko, O. Bazova model NTA v Ukraini: zastosuvannia yevropeiskykh pidkhodiv [Electronic resource] / O. Zalizko, O. Piniazhko. - Access mode: http://www.niss.gov.ua/articles/252/.

16. Shovkaliuk, V. S. Orhanizatsiini formy upravlinnia innovatsiinymy klasteramy / V. S. Shovkaliuk - [Electronic resource]. - Access mode: http://eep.org.ua/files/2009_.pdf.

17. Dubovyk, V. S. Formuvannia innovatsiinykh klasteriv yak metodu aktyvizatsii innovatsiinoi diialnosti v ekonomitsi rehionu / V. S. Dubovyk - [Electronic resource]. - Access mode: http://dspace.nbuv.gov.ua/bitstream/handle/123456789/5907/17-Dubovyk.pdf?sequence=1

18. Smolych, D. V. Kontseptualni zasady formuvannia innovatsiinykh klasteriv v umovakh transkordonnoho spivrobitnytstva rehioniv / D. V. Smolych [Electronic resource]. - Access mode: http://ena.lp.edu.ua:8080/bitstream/ntb/15940/1/31_206-211_Vis_725_Ekonomika.pdf

19. Evropeyskiy klasternyiy memorandum: Podderzhka innovatsiy v Evrope s pomoschyu klasterov: Plan dlya politicheskoy realizatsii [Electronic resource]. - Rezhim dostupa: https://docviewer.yandex.ua/?

20. Yasheva, G. A. Formirovanie mezhdunarodnyih klasterov kak faktor povyisheniya konkurentosposobnostyi ekonomik Rossii, Belarusi, Ukrainyi [Elektronniy resurs] / G. A. Yasheva. - Rezhim dostupu: http://p.120-bal.ru/ekonomika/8211/index.html.

Надійшла до редколегії 18.02.2016 